\title{
Depression in the wives of convicted men: prevalence and associated factors
}

\author{
Depressão em mulheres de apenados: prevalência e fatores associados \\ Depresión en las mujeres de detenidos: prevalencia y factores asociados
}

\section{Débora Cristina Martins Barbosa', Gabriela Ramos Furman', Aliny de Lima Santos", Carlos Alexandre Molena-Fernandes ${ }^{1, \text { III }}$}

\author{
' Universidade Estadual de Maringá, Postgraduate Program in Nursing. Maringá, Paraná, Brazil. \\ "Universidade Estadual de Maringá, Health Sciences Center. Maringá, Paraná, Brazil. \\ II' Universidade Estadual do Páraná, Nursing Department. Maringá, Paraná, Brazil.
}

\begin{abstract}
Martins DC, Furman GR, Santos AL, Molena-Fernandes CA. Depression in the wives of convicted men: prevalence and associated factors. Rev Bras Enferm [Internet]. Rev Bras Enferm [Internet]. 2018;71(Suppl 1):538-45. [Thematic Issue:
\end{abstract}

Contributions and challenges of nursing practices in collective health] DOI: http://dx.doi.org/10.1590/0034-7167-2017-0263

\section{Submission: 05-04-2017 Approval: 08-16-2017}

\section{ABSTRACT}

Objective: To estimate the prevalence of depression and to identify the main risk factors associated with depression in wives of convicted men. Method: Descriptive, cross - sectional, quantitative approach. The data were collected with 349 female partners of convicted patients in three penitentiaries in the state of Paraná, with a semistructured research, between January and June of 2016, being compiled in a database and analyzed using SPSS ${ }^{\circledR} 20.0$ software. Results: It was possible to identify vulnerability to depression among wives of convicted men, most were young and $42.2 \%$ have or already had depression. It was verified that the variables to depression were ages equal to or above 30 years $(50.3 \%, p<0.001)$, smoking $(61.1 \%, p<0.013)$ and alcoholism $(16.1 \%, p<0.001)$. Conclusion: It is the responsibility of the nurse with the multidisciplinary health team to invest in health promotion and prevention actions against these risk factors that were associated with depression in this population.

Descriptors: Depression; Risk Factors; Women's Health; Primary Prevention; Education in Nursing.

\section{RESUMO}

Objetivo: estimar a prevalência de depressão e identificar os principais fatores de risco associado à depressão em mulheres de apenados. Método: estudo descritivo, transversal de abordagem quantitativa. Os dados foram coletados com 349 mulheres parceiras de apenados em três penitenciárias do estado do Paraná, com questionário semiestruturado, entre os meses de janeiro a junho de 2016, sendo compilada em banco de dados e analisada utilizando software SPSS ${ }^{\circledR}$ 20.0. Resultados: foi possível identificar vulnerabilidade para depressão entre mulheres de apenados, a maioria era jovem e 42,2\% têm ou já tiveram depressão. Verificouse que as variáveis à depressão foram idade igual ou acima de 30 anos (50,3\%; $p<0,001)$, tabagismo $(61,1 \%$; $p<0,013)$ e alcoolismo $(16,1 \% ; p<0,001)$. Conclusão: cabe ao enfermeiro junto a equipe de saúde multidisciplinar investir nas ações de promoção, prevenção à saúde frente a estes fatores de risco que foram associados à depressão nesta população.

Descritores: Depressão; Fatores de Risco; Saúde da Mulher; Prevenção Primária; Educação em Enfermagem.

\section{RESUMEN}

Objetivo: estimar la prevalencia de depresión e identificar los principales factores de riesgo asociados a la depresión en las mujeres de detenidos. Método: estudio descriptivo, transversal de abordaje cuantitativo. Los datos fueron recolectados con 349 mujeres compañeras de detenidos en tres prisiones del estado de Paraná, con cuestionario semiestructurado, entre los meses enero a junio de 2016, siendo compilada en base de datos y analizada utilizando el software SPSS ${ }^{\circledR}$ 20.0. Resultados: se identificó la vulnerabilidad para depresión entre mujeres de detenidos, la mayoría era joven y 42,2\% tiene o ya ha tenido depresión. Se ha comprobado que las variables a la depresión fueran de edad igual o superior a 30 años $(50,3 \% ; p<0,001)$, tabaquismo $(61,1 \% ; p<0,013)$ y alcoholismo $(16,1 \% ; p<0,001)$. Conclusión: corresponde al enfermero junto al equipo de salud multidisciplinario invertir en las acciones de promoción, prevención a la salud frente a estos factores de riesgo que se asociaron a la depresión en esta población.

Descriptores: Depresión; Factores de Riesgo; Salud de la Mujer; Prevención Primaria; Educación en Enfermería. 


\section{INTRODUCTION}

Wives of convicted men, not infrequently, experience marked frailty regarding the partner's situation, as they expose themselves to these intimate visits that are programmed through scales. When they arrive at the prison there is certain euphoria between them, but a difference in the humor, the physiognomy, the attitudes and the speeches of these women can be seen. Some come out crying and whining, others have crises of despair for unresolved legal situations and some refer that the return to the home is always a disorder without knowing what may come ahead ${ }^{(1)}$.

There is an invisibility that affects society in reference to the citizen incarcerated, in such a way as if it did not exist, being remembered, sporadically, in the occasion of rebellions. This is mainly due to the fact that prisons are separated from social "views", that is, the prison structure is far from urban centers, with very few exceptions. Still, if such an invisible citizen falls on this invisibility, perhaps his companions, women who maintain an affective bond with people who, in some way, were reneged on social life ${ }^{(2)}$.

Nevertheless, incarceration causes changes in all social and family life contexts, and most of the time it is the woman who exclusively assumes the economic maintenance of the family, the domestic functions, the care with the children, and the accompaniment of all the criminal process of your partner ${ }^{(3)}$. All these responsibilities along with the stigma charged to society, permeated by the rejection complex and the feeling of inferiority, accentuate social vulnerability and exposure to risk factors such as smoking, alcoholism and sedentarism, which in turn leave them with greater pre-disposition of chronic diseases ${ }^{(4)}$.

Thus, the prison environment offers physical and psychological risks to the family. In this sense, the condition of vulnerability of the incarcerated, as well as of their relatives, especially the partner of the victim, should be considered and prioritized in the planning of health care actions ${ }^{(5)}$. Thus, these women are a necessary population to prioritize the risk factors that make them more vulnerable to chronic diseases (CD), especially depression, a disease characterized by a set of psychological and physical symptoms, associated with high rates of medical comorbidities, disability and premature mortality ${ }^{(6)}$. The importance of studies with this population is reiterated, so that strategies can be established for actions aimed at psychosomatic diseases and risk factors linked to these diseases.

The prevalence of depression associated with risk factors such as smoking and alcoholism in women is related to situations of family conflicts, socioeconomic factors, health situations, broken or unstable relationships and stressful episodes such as violence, as well as genetic and biological and hormonal factors. This means that women are more vulnerable to the effects of vital events, which depends not only on genetic-biological factors such as age and reactions of female hormones, but also on environmental factors ${ }^{(7)}$.

To exemplify the magnitude of the disease in Brazil, a study conducted through standardized psychiatric interviews showed the prevalence of depression in 18 countries, including Brazil. The mean prevalence in life and in the last 12 months of major depression (according to DSM-IV) was $14.6 \%$ and $5.5 \%$ in the ten high-income countries and $11.1 \%$ and $5.9 \%$ in the eight low and middle income countries. In Brazil (São Paulo), prevalence in life and in the last 12 months were $18.4 \%$ and $10.4 \%$. Data from all countries show that women are twice as likely to have depression as men. In Brazil, the ratio is 2.6 $6^{(7)}$.

The National Policy for Integral Attention to the Health of Persons Deprived of Liberty in the Prison System (PNAISP) establishes goals regarding the health of the Brazilian prison population, and one of these objectives is the importance of thinking about the health-disease-care process beyond of the individual, thus involving an extended network, such as the family and networks of sociability ${ }^{(8)}$. Regarding the health of wives of convicted men, it is necessary to provide differentiated assistance to the modifiable risk factors that lead to the onset of chronic diseases, as well as to provide their process of interaction with society through the realization of the rights of the human person.

It is important to point out that there are few studies about associations between risk factors and Chronic Diseases, in specific depression, in the population of wives of convicted men, which evidences the lack of information and the need for studies in this area. The findings of the present study may then contribute to future interventions in the prison system with these women. In view of this, the objective of the study was to estimate the prevalence of depression and to identify the main risk factors associated with this disease in wives of convicted men.

\section{METHOD}

\section{Ethical aspects}

Since it is a research involving human beings, all the ethical and legal precepts regulated by Resolution 466/2012 of CNS - MS and the authorization of the Permanent Ethics Committee on Research Involving Human Beings (CETI - FAP) of FAP - Faculdade de Apucarana were obeyed. The request for participation in the study was accompanied by two copies of the Free and Clarified Consent Term (FCCT).

\section{Design, place of study and period}

This is a descriptive study with a cross-sectional and quantitative approach, originated from a master's thesis. In order to sample this study, the three largest penitentiaries in the state of Paraná with a closed prison system and male prisoners in which they received their partners for intimate visits were intentionally selected.

The first penitentiary belongs to the first penitentiary circumscription, located in the municipality of Piraquara. The municipality of Piraquara is located in the southern region of the state of Paraná, its population, according to IBGE (Brazilian Institute of Geography and Statistics) estimates, is 102,798 inhabitants and currently houses the largest penitentiary complex in the state of Paraná with approximately 1,635 males ${ }^{(9-10)}$.

The second penitentiary is located in the northern region of the state, is part of the fourth penitentiary circumscription and belongs to the municipality of Londrina. The municipality of Londrina is located in the southern region of Brazil and north of the state of Paraná, its population, according to IBGE estimates, is 543,003 inhabitants, being the second most populous city in the state of Paraná and the fourth in the south, 
currently housing the second largest criminal complex in the state with approximately 1,150 inmates ${ }^{(9-10)}$.

The third penitentiary located in the Southwest region of the state that is part of the seventh penitentiary circumscription and belongs to the municipality of Francisco Beltrão. The municipality of Francisco Beltrão is located in the southeast region of the state of Paraná, its population, according to IBGE estimates, is 85,486 inhabitants and currently houses the third largest penitentiary complex in the state, with approximately 1,135 inmates ${ }^{(9-10)}$.

The study was developed from January to June 2016.

\section{Study sample, inclusion and exclusion criteria}

According to the Paraná Department of Public Security, approximately $80 \%$ of the victims are visited by their partners and are open to intimate visits on monthly scales due to high demand for visits. The penitentiary in the municipality of Piraquara receives approximately 900 women, while the penitentiary in the municipality of Francisco Beltrão receives approximately 600 women and the penitentiary in the city of Londrina receives approximately 700 women ${ }^{(9)}$. Before the sample number, the statistic was carried out by proportional stratification, in which a total of 366 women were considered divided in the three penitentiaries.

The sample was calculated considering a 95\% confidence level, a desired maximum error of $5 \%$, a proportion in the population of $50 \%$ in order to guarantee greater variability of the studied event and a $10 \%$ increase for eventual losses, totalizing a sample of 349 women distributed in the three largest penitentiaries in the state: 136 women from the municipality of Piraquara, 74 women from the municipality of Francisco Beltrão and 139 women from the city of Londrina.

The women were randomly selected on the days and times scheduled for intimate visits to their partners in penitentiaries. Data collection interviews were conducted in a waiting area in penitentiaries, in a place away from the others, while women waited to enter the visits, seeking the privacy of the interviewees, and ensuring the total secrecy of their information. All female partners of convicted individuals over 18 years of age who agreed to participate in the study were included; women with other degrees of kinship with grievances (mothers, daughters and others) were excluded, as well as those who at the time of the interview were on the effect of alcohol and other illicit drugs.

\section{Study protocol}

Data were collected during the weekends, usually on Fridays, Saturdays and Sundays, between the hours of 5:00 AM to approximately 11:00 AM, with an average duration of 2030 minutes, being conducted by nurses previously trained in the application of the data collection instrument.

In order to collect data, the first part of the survey on Brazilian Study of Sexual Behavior (BSSB) used the model II with 38 questions that was adapted for field research only for women. This instrument, in its first part, seeks to portray the sociodemographic profile and characteristics, as well as some risk factors related to lifestyle and chronic noncommunicable diseases (diabetes, hypertension, heart diseases, depression, and cancer). In the second part, it seeks to identify some types of sexual behaviors that may be related to lack of prevention and other factors that may contribute to Sexually Transmitted Infections (STIS) ${ }^{(11)}$.

\section{Results analysis and statistics}

The information collected was double-typed in an Excel for Windows 2007 spreadsheet in order to correct registry errors, and later analyzed through the Statistical Package for Social Science (SPSS), version 20.0, using descriptive and inferential statistics.

To characterize the sample, we used the descriptive statistics expressed by means of absolute and relative frequency. To verify differences in the proportions between the dependent variable (depression) and the independent variables (age, education, smoking, drugs and physical activity), the Chi-Square test was used. In addition, in 2x2 contingency tables, the Yates Continuity Correction was performed ${ }^{(12)}$.

Multivariate Logistic Regression was used to determine odds ratios or odds ratios (OR) and respective confidence intervals $(95 \%)$, in order to analyze the association of depression with the independent variables. For the inclusion of the independent variables in the multivariate model, the criterion was a level of association of $p \leq 0.20$ with the dependent variable, by the Chi-Square test and later presented in the $p \leq 0.05$ model. The analyses were done through the Statistical Package for Social Science (SPSS), version 20.0, considering $p \leq 0.05$.

\section{RESULTS}

In Table 1, from the total of the sample $(n=349), 39.0 \%$ $(n=136)$ was from the city of Piraquara, 39.8\% $(n=139)$ from Londrina and $21.2 \%(n=74)$ from Francisco Beltrão. Most of the women $(51.9 \%)$ were between 20 and 29 years of age, were of race/white color $(42.1 \%)$, followed by white $(41.5 \%)$. Regarding marital status and number of children, $49.0 \%$ reported living with their "partner" without being officially married, $21.2 \%$ were single and $29.8 \%$ married; and more of half of the women $(53.3 \%)$ have one or two children.

The prevalence of depression $(42.7 \%)$, hypertension $(12.9 \%)$, diabetes $(4.6 \%)$, heart diseases $(4.3 \%)$ and cancer $(3.2 \%)$ was verified in relation to the chronic conditions already established and investigated (Table 2 ).

By means of bivariate analysis, the variables that had an association with depression in female partners were to use tobacco $(p=0.013)$ and alcohol $(p=0.001)$ aged 30 years or more $(p=0.001)$.

In the crude logistic regression analysis according to table 4 , it was verified that women aged $\geq 30$ years had $3.7(95 \%$ $\mathrm{Cl}, 2.3-5.9)$ times more likely to have the disease in relation to those of lower age to 30 years. For education, women who studied until Complete Primary School had $3.5(95 \% \mathrm{Cl}$, 1.2-10.1) times more likely to have depression. On the other hand, those who reported using alcohol and tobacco had an increased odds of 4.1 (95\% Cl 1.8-9.7) and $1.8(95 \% \mathrm{Cl} 1.2-$ 2.8) times respectively have depression.

In the adjusted regression analysis, only age higher than or equal to 30 years and alcohol consumption remained associated with depression, presenting 3.9 (95\% Cl: 2.4-6.4) and $4.2(95 \% \mathrm{Cl}, 8-9.7)$ times more chance, respectively, of 
having depression when compared to the other categories in the same variable (table 4).

Table 1 - Sociodemographic characteristics of wives of convicted men $(\mathrm{N}=349)$, Paraná State, Brazil, 2016

\begin{tabular}{|c|c|c|}
\hline Sociodemographic variables & Total (n) & $(\%)$ \\
\hline \multicolumn{3}{|l|}{ City } \\
\hline Piraquara & 139 & 39.0 \\
\hline Londrina & 139 & 39.8 \\
\hline Francisco Beltrão & 74 & 21.2 \\
\hline \multicolumn{3}{|l|}{ Age Bracket } \\
\hline$>20$ years & 34 & 9.7 \\
\hline $20-29$ years & 181 & 51.9 \\
\hline $30-39$ years & 106 & 30.4 \\
\hline 40 - 49 years & 28 & 8.0 \\
\hline \multicolumn{3}{|l|}{ Race/ Skin Color } \\
\hline White & 145 & 41.5 \\
\hline Brown & 147 & 42.1 \\
\hline Black & 57 & 16.3 \\
\hline \multicolumn{3}{|l|}{ Marital Status } \\
\hline Single & 74 & 21.2 \\
\hline Married & 104 & 29.8 \\
\hline Living together & 171 & 49.0 \\
\hline \multicolumn{3}{|l|}{ Employed } \\
\hline Yes & 143 & 41.0 \\
\hline No & 206 & 59.0 \\
\hline \multicolumn{3}{|l|}{ Number of children } \\
\hline None & 54 & 15.5 \\
\hline $1-2$ & 186 & 53.3 \\
\hline $3-4$ & 102 & 29.2 \\
\hline 5 or more & 7 & 2.0 \\
\hline \multicolumn{3}{|l|}{ Education } \\
\hline Inc. Primary & 109 & 31.2 \\
\hline Comp. Primary & 37 & 10.6 \\
\hline Inc. Secondary & 111 & 31.8 \\
\hline Comp. Secondary & 61 & 17.5 \\
\hline Inc. Higher Educ. & 9 & 2.6 \\
\hline Comp. Higher Educ. & 22 & 6.3 \\
\hline
\end{tabular}

Note: Inc. Primary: Incomplete Primary; Comp. Primary: Complete Primary; Inc. Secondary: Incomplete Secondary; Comp. Secondary: Complete Secondary; Inc. Higher Educ.: Incomplete Higher Education; Com. Higher Educ.: Complete Higher Education.

Table 2 - Noncommunicable Diseases self-reported by wives of convicted men $(\mathrm{N}=349)$. Paraná State, Brazil, 2016

\begin{tabular}{lccc}
\hline *NCDs & & $\mathbf{n}$ & $\mathbf{\%}$ \\
\hline \multirow{2}{*}{ Hypertension } & Yes & 45 & 12.9 \\
\multirow{2}{*}{ Diabetes } & No & 304 & 87.1 \\
& Yes & 16 & 4.6 \\
Cancer & No & 333 & 95.4 \\
& Yes & 11 & 3.2 \\
Heart Diseases & No & 338 & 96.8 \\
\multirow{2}{*}{ Depression } & Yes & 15 & 4.3 \\
\multirow{2}{*}{ Others } & No & 334 & 95.7 \\
& No & 149 & 42.7 \\
& Yes & 200 & 57.3 \\
\hline
\end{tabular}

Note: *NCDs: Noncommunicable Diseases.
Table 3 - Sociodemographic characteristics and risk behaviors in relation to depression in wives of convicted men $(\mathrm{N}=349)$, Paraná State, Brazil, 2016

\begin{tabular}{|c|c|c|c|c|c|c|}
\hline \multirow{2}{*}{ Variables } & & \multicolumn{2}{|c|}{ Total } & \multicolumn{2}{|c|}{ Depression } & \multirow{2}{*}{$p$ value } \\
\hline & & $\mathbf{n}$ & $(\%)$ & $\mathbf{N}$ & $(\%)$ & \\
\hline Age & $\begin{array}{l}<30 \text { years } \\
\geq 30 \text { years }\end{array}$ & $\begin{array}{l}231 \\
118\end{array}$ & $\begin{array}{l}66.2 \\
33.8\end{array}$ & $\begin{array}{l}74 \\
75\end{array}$ & $\begin{array}{l}49.7 \\
50.3\end{array}$ & $<0.001^{*}$ \\
\hline Education & $\begin{array}{l}\text { Inc. Primary } \\
\text { Comp. Primary. } \\
\text { Inc. Secondary } \\
\text { Comp. Secondary } \\
\text { Inc. Higher Educ. } \\
\text { Comp. Higher Educ. }\end{array}$ & $\begin{array}{c}109 \\
37 \\
111 \\
61 \\
9 \\
22\end{array}$ & $\begin{array}{l}31.2 \\
10.6 \\
31.8 \\
17.5 \\
2.6 \\
6.3\end{array}$ & $\begin{array}{c}55 \\
13 \\
44 \\
28 \\
4 \\
5\end{array}$ & $\begin{array}{c}36.9 \\
8.7 \\
29.5 \\
18.8 \\
2.7 \\
3.4\end{array}$ & 0.166 \\
\hline Alcohol & $\begin{array}{l}\text { Yes } \\
\text { No }\end{array}$ & $\begin{array}{c}33 \\
316\end{array}$ & $\begin{array}{c}9.5 \\
90.5\end{array}$ & $\begin{array}{c}24 \\
125\end{array}$ & $\begin{array}{l}16.1 \\
83.9\end{array}$ & $0.001 *$ \\
\hline Smoking & $\begin{array}{l}\text { Yes } \\
\text { No }\end{array}$ & $\begin{array}{l}185 \\
164\end{array}$ & $\begin{array}{l}53.0 \\
47.0\end{array}$ & $\begin{array}{l}91 \\
58\end{array}$ & $\begin{array}{l}61.1 \\
38.9\end{array}$ & $0.013^{*}$ \\
\hline Drugs & $\begin{array}{l}\text { Yes } \\
\text { No }\end{array}$ & $\begin{array}{c}51 \\
298\end{array}$ & $\begin{array}{l}14.6 \\
85.4\end{array}$ & $\begin{array}{c}27 \\
122\end{array}$ & $\begin{array}{l}18.1 \\
81.9\end{array}$ & 0.148 \\
\hline Physical Activity & $\begin{array}{l}\text { Yes } \\
\text { No }\end{array}$ & $\begin{array}{c}79 \\
270\end{array}$ & $\begin{array}{l}22.6 \\
77.4\end{array}$ & $\begin{array}{c}38 \\
111\end{array}$ & $\begin{array}{l}25.5 \\
74.5\end{array}$ & 0.329 \\
\hline
\end{tabular}

Note: *Significant Values $p \leq 0.05$; Inc. Primary: Incomplete Primary; Comp. Primary: Complete Primary; Inc. Secondary: Incomplete Secondary; Comp. Secondary: Complete Secondary; Inc. Higher Educ.: Incomplete Higher Education; Com. Higher Educ.: Complete Higher Education.

Table 4 - Crude and adjusted logistic analysis of factors associated with depression $(\mathrm{N}=349)$, Paraná State, Brazil, 2016

\begin{tabular}{llcc}
\hline Variables & $\begin{array}{c}\text { Crude } \\
\text { Odds ratios } \\
(\mathbf{C l ~ 9 5 \% )}\end{array}$ & $\begin{array}{c}\text { Adjusted } \\
\text { Odds ratios } \\
(\mathbf{C l ~ 9 5 \% )}\end{array}$ \\
\hline Age & $<30$ years & 1 & 1 \\
& $\geq 30$ years & $3.7(2.3-5.9)^{*}$ & $3.9(2.4-6.4)^{*}$
\end{tabular}

Education

Comp. Higher Educ. $\quad 1$ Inc. Primary $1.9(0.6-6.1)$

Comp. Primary $3.5(1.2-10.1)^{*}$

Inc. Secondary $2.9(0.9-8.9)$

Comp. Secondary $2.2(0.8-6.5)$

Inc. Higher Educ. $2.7(0.5-14.2)$

\begin{tabular}{lccc} 
Alcohol & Yes & 1 & 1 \\
& No & $4.1(1.9-9.1)^{*}$ & $4.2(1.8-9.7)^{*}$ \\
Smoking & Yes & 1 & 1 \\
& No & $1.8(1.2-2.8)^{*}$ & $1.6(1.0-2.5)$ \\
\multirow{2}{*}{ Drugs } & Yes & 1 & - \\
& No & $1.6(0.9-2.3)$ & - \\
Physical Activity & Yes & 1 & - \\
& No & $0.8(0.5-1.2)$ & -
\end{tabular}

Note: *Significant Values $p \leq 0.05$; Inc. Primary: Incomplete Primary; Comp. Primary: Complete Primary; Inc. Secondary: Incomplete Secondary; Comp. Secondary: Complete Secondary; Inc. Higher Educ.: Incomplete Higher Education; Com. Higher Educ.: Complete Higher Education. 


\section{DISCUSSION}

The results of this study show the high concentration of depression in convicted partners, where more than $42 \%$ of the study collaborators reported having a history or currently suffering from the disease. In addition, the data also showed the relationship between depression in wives of convicted men and age greater than 30 years and consumption of tobacco and alcohol, where such variables significantly increased the chances of this condition in the population under investigation.

It should be noted that this disease is already recognized as prevalent among the female public, considering that, according to a study carried out in ten countries, showed that women are twice as likely to have depression as men, and in Brazil, the reason is 2.6 times more likely to have depression compared to men ${ }^{(7)}$. Nevertheless, the association between depression and risk factors for age, smoking and alcoholism in women has been investigated in recent years, also showing that social, environmental and family problems directly interfere in the prevalence of the disease ${ }^{(7,13-14)}$.

Epidemiological study of the Ministry of Health (VIGITEL [Telephone-based Surveillance of Risk and Protective Factors for Chronic Diseases] survey) has identified that the prevalence of depression is associated with social inequalities, access difficulties to health services and information, low educational level, and modifiable risk factors such as smoking, alcoholism, of drug, physical inactivity and inadequate feeding ${ }^{(6)}$. In this sense, although they were not associated with the outcome studied, the results of the study show such a profile on the part of the female partners of the victims, where most of them did not finish secondary school (73.6\%) and of these did not complete the Primary School. It can then be considered that such aspects of social vulnerability may affect exposure to predisposing risk factors for chronic conditions such as depression, interfere with access to health services and promotion, the adoption of healthy behaviors and social mobilization for improvement information on risk factors associated with depression ${ }^{(15)}$.

A large proportion of the wives of convicted men depend on the family's seclusion for survival, however, not all of them meet the criteria for obtaining the benefit. In addition, the difficulty experienced by these women in the search for an allocation in the formal labor market, often due to the prejudice towards society or even through the high demand related to the care with the family and until the visits to the imprisoned fellow $^{(8-9)}$. In this sense, the data of the study show that $59.0 \%$ of these women do not work outside and, most of those who work, reported having an informal job as day laborer, saleswoman, manicure and others, and this ends up compromising the family budget and consequently affecting the lifestyle.

Low financial status is therefore a relevant risk factor for the development of mental health problems, such as depression and anxiety disorders, as they are more prone to stressful life situations and limitations of social and economic resources ${ }^{(16)}$.

It should also be noted that data released by the Brazilian Institute of Geography and Statistics (IBGE) showed that in 2010 , depression in women had a higher proportion $(3.3 \%)$ than men $(1.5 \%)$ and that such diagnosis occurred with a greater proportion in those belonging to the age group of 30 to 59 years. Nevertheless, this information corroborates the findings of the present study, where there was an association between depression and age equal to or greater than 30 years, including almost four times more chance of having the disease. In addition, it should be noted that the South and Southeast Regions had the highest percentage of people with diagnosed depression, above the national percentage, $12.6 \%$ and $8.4 \%$, respectively ${ }^{(10,17)}$.

An Australian study in the Journal of the American Heart Association found that middle-aged women diagnosed with depression are 2.4 times more likely to have a heart attack ${ }^{(18)}$. In addition, the impacts of depression on the cardiovascular system are also caused due to behavioral changes caused by the disease. Women with depression or high anxiety levels are more likely to consume alcoholic beverages, cigarettes, drugs, and become more sedentary, thus favoring the onset of heart disease ${ }^{(19)}$, an aspect that was confirmed in the present study by a high percentage of employees who reported using alcohol and tobacco.

Among the findings of the study, the association between depression and tobacco is noteworthy, since such association can directly contribute to the appearance of other chronic diseases such as hypertension, heart disease and chronic respiratory diseases as these women grow older ${ }^{(7)}$. Related to this risk factor, we identified that more than half of the study population $(53.13 \%)$ of wives of convicted men are smokers. In the association between smoking and depression, identifying (61.1\%) of women who have or have already had depression are also smokers. A significant number of tobacco users are identified in this population, since data from the national tobacco control policy of 2013 and the VIGITEL survey between 2014 and 2015 indicate an average of (13\%) for female population smokers in Brazil ${ }^{(6,20)}$.

Based on the above data, an interesting discussion about depression is found, being more common in females and nicotine has an antidepressant effect, since it gives a feeling of relaxation and well-being ${ }^{(13)}$. Then, when the woman begins to give up the addiction, she may go through periods of instability generated by the lack of substance in the body therefore she tends to have more relapses because of anxiety. In this way, the woman usually sees the cigarette as a medicine, as an escape, having the need to smoke to solve a problem and the cigarette ends up "masking" the symptoms of depression (21).

As for modifiable risk factors, smoking has been influential in the CD. Currently, four times more men smoke than women in the world, but as the number of smoking men stabilizes, the number of women smoking continues to increase. In Brazil, World Health Organization (WHO) statistics ${ }^{(6)}$ show that the prevalence of adult smokers reaches $17.5 \%$ of the female population over 15 years of age. In the depressive moods among women, tobacco seems to have an association, as it triggers a sense of well-being.

In a US National Survey, which was conducted between 2005 and 2013 (nine years), on drug use and health showed that smoking decreased significantly over time among adults with no chronic condition. Adults with one or more chronic diseases did not show a comparable decrease with smoking, 
remaining especially high among those reporting anxiety, depression and substance abuse $\mathrm{e}^{(14)}$. This fact was demonstrated in this study, identifying that more than half of the have or have had depression is also a smoker.

Another association evidenced in the study was between the dependent variable depression and the independent variable alcoholism, which were strongly associated, because of the 33 women who report being alcoholics, 24 women have or have already had depression. When comparisons are made between men and women in relation to the consumption of alcoholic beverages in Brazil and in the world, in general, we see that men drink more, with a higher rate of abstention among women, however, studies in the last 10 years have shown a strong incidence among women. According to a survey of alcohol and drugs, this consumption increased by (34.5\%) among women ${ }^{(22)}$.

The prevalence of depression in women who abuse alcohol is $30 \%$ to $40 \%$. Studies have shown that most women with depression drink as a way to get rid of the symptoms associated with depression and that the habit of ingesting alcoholic beverages has been increasing among women ${ }^{(23)}$. The number of women dependent on alcohol has increased in the last decades, according to the "First National Survey on Patterns of Alcohol Consumption in the Brazilian Population". The research investigated in detail how the Brazilian drinks and showed that in two decades the proportion of women among the alcoholic population rose from $10 \%$ to $30 \%{ }^{(24)}$.

Depression with alcohol use is associated with both and is complex, influenced by biological, social and cultural determinants. Female alcoholics have more comorbidity than male alcoholics (65\% women versus $44 \%$ men) and women of the general population (31\% of alcoholics versus $5 \%$ of non-alcoholic women) ${ }^{(14)}$. Another important fact is that alcoholic women frequently present comorbidities with depressive and anxious disorders, unlike men, who present a higher comorbidity with personality disorders. While men have more legal and professional problems, women have more physical and family problems, and the authors also point out that women are more vulnerable to stressful events ${ }^{(25)}$.

Also regarding external determinants, substance abuse by depressed individuals has a close and particular relationship. On the one hand, depressed women abuse alcohol and tobacco to alleviate the symptoms of depression and, on the other hand, suffer from the consequences of such consumption. Among drugs associated with depression, alcohol has a prominence because it is a central nervous system depressant ${ }^{(25)}$.

Perhaps, the lower social and cultural acceptance for female alcohol consumption will work as a protective factor in our country. Over the years, however, social and cultural factors have undergone rapid and profound changes, and concern about the consumption of alcohol among women is a very present issue today ${ }^{(16)}$.

Social inequalities are also related to the development of depressive disorders and associated with risk factors such as alcohol, smoking, physical inactivity and others ${ }^{(13)}$. The contingencies that define these inequalities elicit feelings that are commonly linked to depression, such as humiliation, inferiority, a sense of lack of control over the environment and impotence.
It is also emphasized that the role of the head of the family for women and solitude are also risk factors for depression ${ }^{(26)}$.

The importance of nurses to know the behavior of these morbidities in population samples, especially in vulnerable groups, as in the case of wives of convicted men, as well as their prevalence and forms of association between the risk factors is emphasized. There are few national studies that address comorbid depression and associated risk factors, and their knowledge in our culture is useful in guiding national public policies and clinical approaches, enhancing success and optimizing interventions.

It is understood that women's health promotion strategies related to $C D$, especially depression and control of risk factors such as smoking and alcoholism in this context, should encompass the complexity of the peculiarities experienced by wives of convicted men. The strengthening of the autonomy of the subjects as the essence of the educational process, besides considering science, knowledge and opinions, should bring together the contexts of environmental, social and cultural vulnerabilities ${ }^{(27)}$.

Given this context, it is necessary to reach these individuals with strategies that facilitate communication and understanding with health professionals through differentiated strategies, since the level of education is one of the defining of the conduct that the individual assumes within the health-disease process and as it establishes its own mechanisms and has access to others to maintain its state of health. When performing health education, people are allowed to have greater autonomy in decision making in their lives and, consequently, less exposure to these risk factors that will contribute to decrease morbidity and mortality for this disease ${ }^{(28)}$.

\section{Study limitations}

Considering the importance of the results obtained, despite the inclusion of 3 large penitentiaries and the number of women in this sample, the study presents the limitation because it was performed only in one state of the southern region of Brazil. It should be noted that the number of grievances in Brazil is increasing considerably, and with this, the increase of women within these institutions in different regions of the country, being necessary studies with wives of convicted men in other territories to allow the generalization of their findings.

Contributions to the area of nursing, health and public policy

Thus, the quality of care for these women in specific needs to be planned by a multidisciplinary team, focused on ensuring the promotion and respect for human rights that ensure integral health and well-being within the Policies of Integral Attention to Women's Health (PAISM)(29) and also of the National Policy for Integral Attention to Persons Deprived of Liberty in the Prison System (PNAISP), since it must be considered that there is a significant number of women suffering from prisons and penitentiaries in Brazil with diseases chronic and with associated risk factors with much higher proportions within the epidemiological indicators. It is believed that the results of this study may contribute to future research, in which it will be possible to investigate the partner wives of convicted men in other 
regions of Brazil, with strategies to strengthen nursing practices and the insertion of other professionals within the promotion and prevention actions in health for this population.

\section{CONCLUSION}

This study presents important results of association between depression disease and risk factors such as age, alcoholism and smoking in wives of convicted men, responding to the objective of the research and contributing to the advancement in research and practices of promotion, prevention and nursing interventions in a vulnerable population.

Given these results, it was observed that in the prison environment is the partner woman of the victim who participates in all criminal and criminal proceedings and also assumes all family responsibilities. By means of these responsibilities it is perceptible that the woman becomes fragile with excessive levels of anxiety, situations of stress and uncertainties, thus, some may trigger psychosomatic diseases, the most prevalent being depression. Thus, this disease may be associated with these and other risk factors.

Therefore, the needs of the nursing team, along with other health professionals, work with a view to creating greater links with this population with information transfer and sensitization to the conditioning risk factors as well as chronic diseases. It is worth stressing the importance of thinking about the health-disease-care process in addition to the incarcerated individual, thus involving an expanded network to insert the woman of the victim in the National Policy of Persons Deprived of Liberty within the territory of the Family Health Strategy program and in the Policy of Integral Attention to Women's Health.

\section{REFERENCES}

1. Bassani F. Amor Bandido: cartografia da mulher no universo prisional masculino. Dilemas: Rev Est Confl Contr Social UFRJ [Internet]. 2011 [cited 2016 Sep 10];4(2):261-80. Available from: http:// https://revistas.ufrj.br/index.php/dilemas/article/view/7225/5813.pdf

2. Paula ACMC, Santana IS. Inobservância do princípio da intransmissibilidade da pena: aplicação em relação às mulheres que mantêm relacionamento afetivo com apenados. An Sciencult[Internet]. 2012 [cited 2016 Dec 10];4(1):22-8. Available from: http:// anaisonline.uems.br/index.php/semex/article/view/455/453.pdf

3. Barcinski M, Lermen HS, Campani C, Altenbernd B. Guerreiras do cárcere: uma rede virtual de apoio aos familiares de pessoas privadas de liberdade. Temas Psicol [Internet]. 2014 [cited 2015 Oct];22(4): 929-40. Available from: http://pepsic.bvsalud.org/pdf/ tp/v22n4/v22n04a19.pdf

4. Nicolau AIO, Ribeiro SG, Lessa PRA, Monte AS, Ferreira RCN, Pinheiro AKB. A picture of the socioeconomic and sexual reality of women prisoners. Acta Paul Enferm [Internet]. 2012 [cited 2016 Nov 29];25(3):386-92. Available from: http://www.scielo.br/ pdf/ape/v25n3/v25n3a11.pdf

5. Martinho S. Uma política para garantir o direito à saúde no sistema prisional [entrevista a Dominguez B]. In: Radis Comun Saúde [Internet]. 2012 [cited 2015 Nov 05];118:20-1. Available from: http://www6.ensp.fiocruz.br/radis/revista-radis/118/reportagens/ uma-politica-para-garantir-o-direito-saude-no-sistema-prisional

6. Brasil. Ministério da Saúde. Secretaria de Vigilância em Saúde. Secretaria de Gestão Estratégica e Participativa. Vigitel Brasil. Vigilância de fatores de risco e proteção para doenças crônicas por inquérito telefônico [Internet]. 2015 [cited 2016 Feb 22] Brasília, DF: Ministério da Saúde, 2015. Available from: http://www.ans.gov.br/images/stories/Materiais para pesquisa/Materiais por_assunto/2015_vigitel.pdf

7. Bromet E, Andrade LH, Hwang I, Sampson NA, Alonso J, Girolamo G, et. al. Cross-national Epidemiology of DSM-IV major Depressive Episode. BMC Med [Internet]. 2011 [cited 2016 Feb 19];9(90):1-16. Available from: https://bmcmedicine.biomedcentral.com/ articles/10.1186/1741-7015-9-90

8. Brasil. Ministério da Saúde. Portaria Interministerial no 1, de 2 de janeiro de 2014. Institui a Política Nacional de Atenção Integral à Saúde das Pessoas Privadas de Liberdade no Sistema Prisional (PNAISP) no âmbito do Sistema Único de Saúde (SUS). Diário Oficial da União 2 jan 2014

9. Brasil. Ministério da Justiça. Departamento Penitenciário Nacional. Sistema Integrado de Informações Penitenciárias: InfoPen [Internet]. Brasília, DF: Ministério da Justiça, 2013 [cited 2015 Feb 20]. Available from: https://www.justica.gov.br/...infopen.../ relatorio-depen-versao-web.pdf

10. Brasil. Instituto Brasileiro de Geografia e Estatística. Coordenação de população e indicadores sociais, projeções da população do Brasil por sexo e faixa etária-revisão 2008. Rio de Janeiro: IBGE, 2012

11. Abdo CH, Moreira JRED, Fittipald JAS. Estudo do Comportamento Sexual no Brasil - ECOS. Rev Bras Med [Internet]. 2002 [cited 2015 Mar 10]. Available from: http://www.moreirajr.com.br/revistas.asp?fase = r003\&id_materia $=196$

12. Marconi MA, Lakatos EM. Técnicas de pesquisa. 7a ed. São Paulo: Atlas; 2010

13. Hermens DF, Scott EM, White D, Lynch M, Lagopoulos J, Whitwell BG, et al. Frequent alcohol, nicotine or cannabis use is common in young persons presenting for mental healthcare: a cross-sectional study. BMJ [Internet]. 2012 [cited 2016 Aug 22];3(2):1-10. Available from: http://bmjopen.bmj.com/content/bmjopen/3/2/e002229.full.pdf 
14. Slade T, Chapman C, Swift W, Keyes K, Tonks Z, Teesson M. Birth cohort trends in the global epidemiology of alcohol use and alcohol-related harms in men and women: systematic review and meta regression. BMJ [Internet]. 2016 [cited 2016 Dec 19];6(10):1-12. Available from: http://bmjopen.bmj.com/content/bmjopen/6/10/e011827.full.pdf

15. Andrade JMO, Rios LR, Teixeira LS, Vieira FS, Mendes DC, Vieira MA, et al. Influence of socioeconomic factors on the quality of life of elderly hypertensive individuals. Cienc Saude Colet [Internet] 2014 [cited 2015 Dec 10];19(8):3497-504. Available from: http://www.scielo.br/pdf/csc/v19n8/1413-8123-csc-19-08-03497.pdf

16. Campos JR, Prette AD, Prette ZAP. Depression in adolescence: social skills and sociodemographic variables as risk factors/ protection. Estud Pesqui Psicol[Internet]. 2014 [cited 2015 Nov 28];14(2):208-28. Available from: http://pepsic.bvsalud.org/pdf/ epp/v14n2/v14n2a03.pdf

17. Organização Mundial da Saúde. Fact sheet no 369: Depression [Internet]. 2015 [cited 2016 Apr 22]. Available from: http://www. who.int/mediacentre/factsheets/ fs369/en/

18. Shah JA, Ghasemzadeh N, Zaragoza-Macias E, Patel R, Eapen DJ, Neeland IJ, et al. Sex and age differences in the association of depression with obstructive coronary artery disease and adverse cardiovascular events. J Am Heart Assoc[Internet]. 2014 [cited 2016 Nov 19];3(741):1-10. Available from: https://www.ncbi.nlm.nih.gov/pmc/articles/PMC4309058/pdf

19. Ribeiro AG, Cotta RMM, Ribeiro SMR. The promotion of health and integrated prevention of risk factors for cardiovascular diseases. Ciênc Saúde Colet[Internet]. 2012 [cited 2015 Dec 13];17(1):7-17. Available from: http://www.scielo.br/pdf/csc/v17n1/ a02v17n1.pdf

20. Vieira LB, Cortes LF, Padoin SMM, Souza IEO, Paula CC, Terra MG. Abuse of alcohol and drugs and violence against women: experience reports. Rev Bras Enferm[Internet] 2014 [cited 2015 Dec 12];67(3):366-72. Available from: http://www.scielo.br/pdf/ reben/v67n3/0034-7167-reben-67-03-0366.pdf

21. Pinto MT, Riviere AP, Bardach A. The burden of smoking-related diseases in Brazil: mortality, morbidity and costs. Cad Saúde Pública[Internet] 2015 [cited 2016 Mar 29];31(6):1283-97. Available from: http://www.scielo.br/pdf/csp/v31n6/0102-311Xcsp-31-6-1283.pdf

22. Caetano R, Madruga C, Pinsky I, Laranjeira R. Patrones de consumo de alcohol y problemas asociados en Brasil. Adiciones [Internet]. 2013 [cited 2015 Dec 13];25(4):287-93. Available from: http://inpad.org.br/wp-content/uploads/2013/03/Madruga_ Caetano.pdf

23. Oliveira GC, Carvalho MDB, Pelloso SM, Ballani TSL, Agnolo CMD. Consumo abusivo de álcool em mulheres. Rev Gaúcha Enferm [Internet]. 2012 [cited 2016 Dec 10];33(2):60-8. Available from: http://www.scielo.br/pdf/rgenf/v33n2/10.pdf

24. Brasil. Secretaria Nacional Antidrogas, Gabinete de Segurança Institucional. I levantamento nacional sobre os padrões de consumo de álcool na população brasileira [Internet]. Brasília (DF): Secretaria Nacional Antidrogas. 2007. 40p. Available from: http://bvsms. saude.gov.br/bvs/publicacoes/relatorio_padroes_consumo_alcool.pdf

25. Gjestad R, Franck J, Hagtvet KA, Haver B. Level and change in alcohol consumption, depression and dysfunctional attitudes among females treated for alcohol addiction. Alcohol Alcohol [Internet]. 2011[cited 2016 Sep 10];46(3):292-300. Available from: http://www.ncbi.nlm.nih.gov/pubmed?term = 21414951.pdf

26. Pereira EL. Families of incarcerated women, health promotion and access to social policies in the Federal District, Brazil. Cienc Saude Colet [Internet]. 2016 [cited 2016 Dec 19];21(7):2023-34. Available from: http://www.scielo.br/pdf/csc/v21n7/1413-8123csc-21-07-2123.pdf

27. Geniole LI, Jaoglanian VLK, Vieira CCA. A saúde da família em populações carcerárias. Campo Grande. MS: Ed. UFMS: Fiocruz Unidade Cerrado Pantanal; 2011.

28. Manso MEG, Câmara R, Suely A, Farina LL. Programa de gerenciamento de doenças crônicas em um plano de saúde, São Paulo, Brasil. Cienc Cuid Saude[Internet]. 2016 [cited 2016 Dec 19];15(2):321-7. Available from: http://periodicos.uem.br/ojs/index.php/ CiencCuidSaude/article/view/28683

29. Brasil. Ministério da Saúde. Plano Nacional de Políticas para as Mulheres 2013-1015. Brasília, DF: Ministério da Saúde, 2013. 